\title{
ANDREA MEYERTHOLEN
}

University of Indiana, Bloomington

\section{Apocalypse Now: On Heinrich von Kleist, Caspar David Friedrich, and the Emergence of}

\section{Abstract Art}

Abstract: While discussions of abstract art usually imply that the movement began in the twentieth century, its conceptualization pre-dates its identification as a distinct tendency in the visual arts. One early text that articulates the premises of abstract art is Heinrich von Kleist's "Empfindungen vor Friedrichs Seelandschaft," his narrative response from 1810 to Caspar David Friedrich's controversial painting Der Mönch am Meer. For all its inherent radicality and despite its departure from mimetic representation, Der Mönch am Meer does not constitute a leap on the part of Friedrich to abstract aesthetics. Rather, I will argue that, in his re-imagining of Der Mönch am Meer, Kleist crosses this threshold, constituting a vision of nonrepresentational art nearly a century prior to its purported existence. As I will establish by examining both painting and prose, what Friedrich anticipates with his visual image, Kleist describes in his written text.

Article

All art is an abstraction from reality, from cave paintings to naturalist depictions of the perceptual world. However, not all art is an abstraction in service of reality. While some artworks provoke onlookers to reflect upon the discrepancy between artistic representation and 
reality, others tend to lead observers to forget it. Some works of art also seem to solicit later observers to notice abstract moments where contemporaries did not, and vice versa. Thus, to ascribe "the" discovery or invention of abstract art to any specific artwork or artist would be problematic. ${ }^{1}$ Nevertheless, examining how onlookers of a given artwork have perceived its abstract moments remains quite fascinating and relevant to our understanding of not only art, but also literature. Written documents of critics, connoisseurs, and philosophers form a history in their own right, many histories even, of reflections about abstraction in art, each of which entails specific registers of description for abstraction. This essay will feature one such written reflection and the distinct form of abstraction it engenders. The choice of this particular written reflection is neither arbitrary nor unfounded. Though existing before Kandinsky, it belongs to one of the multiple lineages of abstraction in the visual arts that will lead to and beyond Kandinsky, as well as those other artists who initially realized the promise of nineteenth-century literary imaginings of abstract art in the twentieth century. Yet this unpainted, originary moment of abstract art did arise from an artwork, one which, though still attempting to portray reality, did so in a manner so abstracted that it provoked a conceptual shift in one critical viewer. The artwork is Caspar David Friedrich's Der Mönch am Meer, and its critical viewer was Heinrich von Kleist.

Indeed, this early imagining of abstract art finds expression through narrative form in Kleist's 1810 commentary "Empfindungen vor Friedrichs Seelandschaft." ${ }^{2}$ Kleist's short prose piece is perhaps the most famous reaction to a controversial artwork that created a stir because of its audacious flouting of tradition and convention. For all its inherent radicality and despite its departure from mimetic representation, Der Mönch am Meer as painted by Friedrich does not constitute a leap to abstract art as such. ${ }^{3}$ Rather, I will argue that Der Mönch am Meer as re- 
imagined by Kleist crosses this the threshold of abstraction, constituting a vision of nonrepresentational art nearly a century prior to its purported existence. As I will establish by examining both painting and prose, what Friedrich anticipates with his visual image, Kleist describes in written text.

In the first part of my article, I will introduce Friedrich's Der Mönch am Meer, demonstrating why the artist did not create an abstract work of art, but highlighting aspects of this painting which that most likely inspired Kleist to do so. The second section presents an analysis of Kleist's "Empfindungen vor Friedrich's Seelandschaft” in which I identify the moment when Kleist articulates a new register of abstraction for the visual arts, a register whose definition I subsequently derive and discuss. To conclude, I address Kleist's aesthetic legacy by considering how the abstract image envisioned in his nineteenth-century narrative is actualized in the abstract paintings of several predominant artists of the twentieth century.

\section{The Lone Man and the Sea}

As far as early nineteenth-century paintings go, Friedrich's Der Mönch am Meer is many things: reductive, monochromatic, spatially flat, even avant-garde. ${ }^{4}$ It is not, however, abstract. ${ }^{5}$ In fact, the objects depicted on the canvas are quite banal; the spectator observes exactly what the title suggests, namely a monk by the sea. From the horizontal strips of sea, sand, and sky to the lone figure of the monk, the artwork consists solely of recognizable elements transcribed from the natural world, but recombined to represent the painter's version of our given reality. That scholars commonly accept the figure of the monk as one of Friedrich's self-portraits further anchors the painting in the perceptual world. ${ }^{6}$ From our twenty-first-century perspective, we might wonder how this ostensibly simple seascape with its little monk before a great sea could 
cause so much irritation and such inspiration in its various contemporary viewers. ${ }^{7}$ To facilitate a deeper understanding of how this painting opened the horizons of what art could express and how it could appear, I will situate Friedrich within a larger context of nineteenth-century landscape painting and designate some of the more subversive and innovative aspects of Der

\section{Mönch am Meer.}

In an era dominated by the normative precepts of classical landscape painting and audience expectations thereof, Der Mönch am Meer proves quite extraordinary. While Friedrich does not break with the codified habits of Western illusionism or reject the transcription representation of recognizable objects, he does depart from them. ${ }^{8}$ In this very departure lies the abstracted, but not abstract, quality of his work. The artist initiates a move away from the objective world by emptying his canvas of objects. Whereas nineteenth-century audiences were accustomed to groupings of precisely transcribed and readily recognizable figures strategically positioned to guide the spectator through the painting, Friedrich removes such visual cues by dissolving and even obliterating forms outright, a process already manifest in his painting from 1807, Meeresstrand im Nebel. Depicting two boats just offshore, which are barely visible behind a thick blanket of fog, Friedrich plays with themes of departure in terms of content and style. As the ships disappear from shore, they also disappear from the spectator's sight. ${ }^{9}$ Friedrich builds up multiple layers of paint over the objects until a wall of fog very nearly conceals their forms, but it is not until the completion of Der Mönch am Meer that Friedrich fully realizes this dissolution of form. Eyewitness accounts and more recent x-rays provide evidence that Friedrich had originally painted sailing ships on the ocean as well as astral bodies in the heavens. ${ }^{10}$ Over the course of several revisions, he deliberately expunged these objects from the picture until the monk stood alone amid the topographical trinity of sand, sea, and sky. ${ }^{11}$ The systematic erasure 
of all distraction save for this skeletal framework empties the central space of the canvas, a maneuver which in turn advances the creation of a new object; namely, the central space of the canvas.

The presence of this absence is further enhanced through the artist's disruption of conventional compositional structure, linear perspective, and scale. ${ }^{12}$ Such tactics had already brought Friedrich to the public's attention just a year earlier when the conservative art critic Basilius von Ramdohr printed a vitriolic critique of the altarpiece Das Kreuz im Gebirge for its lack of spatial unity, illogical aerial perspective, and overall offense against the rules of optics. ${ }^{13}$ However, the so-called Ramdohr dispute did little to discourage Friedrich from taking more extreme liberties with formal principles of the art world. Whereas classical landscape painting as exemplified by Poussin or Lorrain produces the optical illusion of a three-dimensional world in consonance with human perception, in Der Mönch am Meer Friedrich works actively to dispel it. He does not enclose the painting with trees, buildings, or other outstanding figures that would push the eye toward the central scene and increase the sense of depth. Rather, his framing strategy consists of the platform of sand running along the bottom of the painting. This natural border is paralleled by the horizon line, which, though traditionally drawn at or above eye-level, seems here to plunge downward under the weight of the sprawling sky. With no repoussoir to restrain the already enlarged space, the painting also has no outstanding verticals or incidental figures to interrupt its uniform horizontality.

Having already expunged superfluous objects, Friedrich dissolves the natural boundary between sea and sky with heavy cloud coverage. Clouds, along with other naturally occurring cloaking devices such as fog and mist, were frequently deployed by the artist to obscure horizon lines and shroud frontiers. The absence of limits and clearly defined perimeters provokes 
expectation and uncertainty, atmospheric effects which can be exhilarating as in Wanderer über dem Nebelmeer, or ominous as in Abtei im Eichwald. In Der Mönch am Meer, Friedrich achieves both effects; the dynamic dark clouds, which the artist painted into the composition at a later stage, obfuscate the abnormally low horizon line. ${ }^{14}$ At once thrilling and threatening, they effectively merge the two layers into one immense body, a cohesion Friedrich intensifies with a monochromatic color palette of surging blues and grays. ${ }^{15}$

By collapsing the distinction between sea and sky, Friedrich also robs the composition of its middle ground. As in Wanderer über dem Nebelmeer and Kreidefelsen auf Rügen, Friedrich foregoes the orderly succession of background layers, which, according to the conventions of Western perspective, should gradually recede into the painting. Instead, foreground is placed directly adjacent to background, a bold juxtaposition made even more visually jarring through color contrast. ${ }^{16}$ The thin band of pale sand appears infinitely disconnected from the darkness beyond, causing the painting to lose the illusion of depth and gain a flatness of space. ${ }^{17}$ What emerges is an image at odds with perceptual reality and thus difficult for the eye to navigate. The composition offers little structural orientation, only a multiplicity of underlying diagonals leading not to a unified vanishing point, but to nowhere. Though drawn upwards, the eye is left to wander aimlessly, trapped in the flat field of sky. Given the large scale of the painting and its narrow foreground, a general impression of interminable emptiness and limitlessness emerges, rendering the vacant space the focal point of the painting, as if the gaping void were an object in and of itself. Occupying roughly four-fifths of the picture plane, such an expansive and uninterrupted field of color must have presented a startling sight to nineteenth-century audiences. $^{18}$ 
Despite his minimalist approach, Friedrich has not cleared the canvas only to leave it devoid of content. He is just not the one to supply it. As his own writings about this painting indicate, the artist sets the empty stage by assembling a framework of forms from the objective world:

Es ist nemlich ein Seestük, vorne ein öder sandiger Strand, dann, das bewegte Meer, und so die Luft. Am Strande geht tiefsinnig ein Mann, im schwarzen Gewande; Möwen fliegen ängstlich schreiend um ihn her, als wollten sie ihn warnen, sich nicht auf ungestümen Meer zu wagen. ${ }^{19}$

With simple words and forthright manner, Friedrich sketches the basic premise of the seascape and the objects it contains. However, this objective description precipitates a subjective turn, as the artist abruptly changes tone:

Dies war die Beschreibung, nun kommen die Gedanken:

Und sännest du auch vom Morgen bis zum Abend, vom Abend bis zur sinkenden Mitternacht; dennoch würdest du nicht ersinnen, nicht ergründen, das unerforschliche Jenseits! Mit übermüthigem Dünkel, erwegst du [...] zu enträtseln der Zukunft Dunkelheit! [...] Tief zwar sind deine Fußstapfen am öden sandigen Strandte; doch ein leiser Wind weht darüber hin, und deine Spuhr wird nicht mehr gesehen: Thörichter Mensch voll eitlem Dünkel!-

Speaking as if the reader were already embedded in the scene, Friedrich addresses us, ("Und sännest $d u$," "würdest $d u$," "erwegst $d u$ "), urging, almost demanding, that we walk in the monk's sandy footprints. When looking outward, the object of our gaze would be not wind or water, but 
a limitless expanse, too dark to discern forms and too inscrutable to fathom. Despite the futility of our efforts, the artist suggests that we, "thöricht" and "voll eitlem Dünkel," would wantonly and arrogantly try anyway. Some may find this struggle uplifting and exhilarating, others humbling and demoralizing; the sentiments or ideas evoked within us to fill this empty realm are particular to our experience. Friedrich does not dictate our reactions and cannot control our feelings, but frames the empty space as an arena for aesthetic response and calls upon the spectator to fill in the blank.

This same demand is occasioned by the painting through the inclusion of one of the artist's famous Rückenfiguren. ${ }^{20}$ Not as imposing as the monumental wanderer, the diminutive figure in Der Mönch am Meer is nonetheless granted privileged status by his location near the Golden Section. ${ }^{21}$ With his back to the audience, the monk serves as a point of identification, an implicit invitation to step into his metaphorical shoes, or in this instance, stand in his footprints. Doing so, we become the individual on the edge of this natural frontier, confronting the mysteries of metaphysical space; and as the monk, we no longer see his figure (or any other object on canvas for that matter), only the interminable distance of which Friedrich writes. ${ }^{22}$ Thus, this moment of identification preconditions the moment of abstraction in the aesthetic reception of Friedrich's painting. This anticipatory moment is revisited by Friedrich to varying degrees in subsequent paintings, most notably in Kreidefelsen auf Rügen and Wanderer über dem Nebelmeer. Through these Rückenfiguren, the audience ventures out vicariously onto rocky precipices to confront the sudden plunge into a looming expanse likewise created by veiled boundary lines and broken perspectival axes. While both sea and sea of fog are still relatively recognizable, the dark forms beyond the monk and his sandy scaffolding deteriorate into an 
abstracted abyss. For a fleeting moment, the artist brings us to the threshold of a new type of image that places new demands on the viewer.

Yet the threshold is as far as we go. Although Friedrich's forms are abstracted, he never fully departs from his constructed framework of representational objects. He indicates the possibility of abstract art, suggests what it might look and feel like, and even anticipates techniques used to achieve it; but indicating, suggesting, and anticipating are not the same as actually doing. Remaining in the realm of its precondition, the artist brings us to the brink of abstract art, but, as implied by the deep impressions left in the sand in Der Mönch am Meer, our feet never leave the safety of the shore. While the promising aesthetic experience described in Friedrich's writing does not materialize when put to canvas, he articulates and prepares the departure from the abstracted forms into an autonomous abstract image. Remarkably enough, this image does not appear decades later when the virtues of hindsight and subsequent aesthetic developments would foster more favorable attitudes toward Friedrich's work, nor does it spring from the mind of a fellow artist. Instead, this vision of abstract art emerges the very same year from the imagination of Heinrich von Kleist, a writer who, upon witnessing the painting's unveiling at the 1810 Berlin Academy exhibition, perceives the revolutionary potential of Friedrich's ideas. He recognizes that the artwork does not generate as evocative and absorbing an aesthetic experience as it could, yet sees the emptiness of Der Mönch am Meer as a space full of possibility. In revealing one such possibility through narrative image, Kleist tears the ground out from under the spectator's feet and sends us plunging into an instance of abstract art well before its recognized emergence.

\section{Brave New World}


For such a momentous moment, Kleist's published response to the painting, "Empfindungen vor Friedrichs Seelandschaft," is surprisingly brief and yet incredibly fraught with significance for the birth of abstract art. In its few lines, Kleist praises Friedrich's revolutionary aesthetic, identifies its inherent limitations, and then supersedes them himself by painting a picture, albeit figuratively, which is even more radical. The opening text places us, the viewer, right where Friedrich and his painting presumably left us, at the edge of the earth facing the boundless sea:

Herrlich ist es, in einer unendlichen Einsamkeit am Meeresufer, unter trübem Himmel, auf eine unbegrenzte Wasserwüste, hinauszuschauen. Dazu gehört gleichwohl, da $\beta$ man dahin gegangen sei, da $\beta$ man zurück mu $\beta$, da $\beta$ man hinüber möchte, da $\beta$ man es nicht kann, da $\beta$ man alles zum Leben vermi $\beta \mathrm{t}$, und die Stimme des Lebens dennoch im Rauschen der Flut, im Wehen der Luft, im Ziehen der Wolken, dem einsamen Geschrei der Vögel vernimmt. Dazu gehört ein Anspruch, den das Herz macht, und ein Abbruch, um mich so auszudrücken, den einem die Natur tut. (327)

Conspicuously absent from this initial scene is the monk, but for good reason: as opposed to Friedrich's description, we do not begin outside Der Mönch am Meer; we are already in it. Kleist situates the reader directly on the shores of the objective world, not observing it remotely or as mediated by the framework of a painting.

Once again we encounter a demand of sorts, an "Anspruch."23 Yet Kleist's "Anspruch" is not analogous to Friedrich's call to the spectator to identify with the monk. Here, the viewer is 
issuing the appeal, an appeal from the heart to cross over. In Kleist's language, our struggle to “cross over" amounts to a question of boundaries (“da $\beta$ man dahin gegangen sei," "da $\beta$ man zurück mu $\beta$," “da $\beta$ man hinüber möchte"). Faced with a limitless expanse, we demand to place within the bounds of human understanding what lies beyond its limits. We want to comprehend the incomprehensible, to acquire knowledge of the unknowable. In essence, we want to make the infinite finite by imposing our own framework upon it. Kleist, like Friedrich, acknowledges the futility of this endeavor, conceding, “da $\beta$ man es nicht kann.” Our appeal is answered with a rejection in the form of Nature's "Abbruch," for crossing the ocean to frame it as an object of human experience is an impossibility. Yet it is enough of an imaginative possibility to arouse the "herrlich[en]" and intense wish within our hearts to do so.

Friedrich's painting, however, does not allow for this possibility, and so fails to elicit the effect Kleist desires from it:

Dies aber ist vor dem Bilde unmöglich, und das, was ich in dem Bilde selbst finden sollte, fand ich erst zwischen mir und dem Bilde, nämlich einen Anspruch, den mein Herz an das Bild machte, und einen Abbruch, den mir das Bilde tat [...].

In comparing these dueling seascapes, the one he sees and the one he "should" find, Kleist points to a fundamental discrepancy between the aesthetic response to imitated reality and reality itself. Gazing into Friedrich's painted reproduction of the ocean will not necessarily generate the same effect or affect as gazing into the actual ocean. By occupying the monk's shoes, Kleist's feet will never leave the shore and hence stay rooted in the objective world. He perceives the potential in Friedrich's painting to evoke sentiments that are truly "herrlich," while also recognizing that the artist is not iconoclastic enough. How can Kleist struggle to frame the formless fields before him 
if Friedrich has already done so through the very framework provided by the painting? Its objective forms, however abstract, mitigate the immediacy of the encounter. What Kleist "in dem Bilde selbst finden sollte"-namely, an unmediated and unframed experience of what he beholds - he does find, but "erst zwischen mir and dem Bilde" (my emphasis). Instead of a representation of this dynamic portrayed in the painting, Kleist's imagination creates the dynamic itself as occurring between viewer and painting.

To do so, the author transposes Friedrich's arrangement of monk, shore, and sea, writing: [...] und so ward ich selbst der Kapuziner, das Bild war die Düne, das aber, wo hinaus ich mit Sehnsucht blicken sollte, die See, fehlte ganz. Nichts kann trauriger und unbehaglicher sein, als diese Stellung in der Welt: der einzige Lebensfunke im weiten Reiche des Todes, der einsame Mittelpunkt im einsamen Kreis. Das Bild liegt, mit seinen zwei oder drei geheimnisvollen Gegenständen, wie die Apokalypse da, als ob es Youngs Nachtgedanken hätte [...]. (327)

Situating himself as monk and the painting as dune, Kleist removes both objects from sight, effectively clearing the image of Friedrich's framing devices. From this vantage point, nothing is left in the empirical world to experience, as the imagined scenario dispenses with any framework that would intercede or distance spectator from spectacle. Fully departing from earthly reality, we arrive at an infinite expanse of a new world where we are fully alone with and absorbed in the vision of boundless space, the "einsame Mittelpunkt im einsamen Kreis." From roaring surf to crying gulls, all distinct boundaries and knowable objects are gone, and what few amorphous shapes remain dissipate into oblivion. A canvas lacking forms, perspective, indeed any reference 
to given reality, this absolute nothingness unfolds like the Apocalypse before the viewer. With no framework of representational objects, this image is abstract, but is it art?

Continuing his narrative, Kleist explicitly and rather graphically conveys to the reader how this emptiness evokes an aesthetic response:

[...] und da es, in seiner Einförmigkeit und Uferlosigkeit, nichts, als den Rahm, zum Vordergrund hat, so ist es, wenn man es betrachtet, als ob einem die Augenlider weggeschnitten wären. ${ }^{24}$

Here is the moment in which abstract art is envisioned. The void elicits an aesthetic response akin to having had one's eyelids sliced off, an affect with metaphorical dimensions but real implications. ${ }^{25}$ Unable to close, lidless eyes are compelled to look but have no means to limit or distance themselves from the object of perception. The eye is exposed, vulnerable; it is unable to protect itself, block out what it witnesses, or exercise authority over what it sees. With no means to obstruct the visual flood or gain some measure of control, the eye plunges into an overwhelming image that envelops the entire field of vision. ${ }^{26}$ This collapse of boundaries ensuing from an incident of bodily mutilation recalls Kleist's Penthesilea, but instead of a desiring subject consuming an aesthetic object, the situation is reversed. ${ }^{27}$ The image dominates the eye in this aesthetic experience, and, by extension, absorbs the entire body. Here is where written reflection opens a new register of abstraction for visual art. As derived from Kleist's description, this register of abstraction is defined by the loss of internal and external framing devices proceeding from 1) the absence of internal division between foreground and background, and from 2) the lack of external control mechanisms. The loss of a referential framework tying the image, however loosely, to perceptual reality results in the loss of 
recognizable objects, of scale and perspective, of measurability and proportion. With nothing to separate the viewing subject from the object of perception; with no frame enclosing and presenting the image as a totality, the aesthetic experience is boundless.

The moment we lose our eyelids is also the point of no return. Kleist and his frameless image not only abandon us to the expanse, but cut off our means of finding a way out. Friedrich's Der Mönch am Meer challenges the authority of the eye and undermines its expectations, but does not completely sever it from its mechanisms of security and control. Although Friedrich departs from Western illusionism and its strategies of representing the objective world, he still supplies the spectator with sufficient visual markers to measure distance and scale, discern discrepancies of perspective, and make sense of the image. We never lose our eyelids, so to speak, because Friedrich never fully departs from the framing devices that anchor his image in our knowable and calculable reality. The infinite space abstractedly framed and contained frustrates, even threatens, the ability to comprehend, but we can always employ our own framing devices, our eyelids, as instruments of control. In this manner, we reestablish our footing on the shore, confirming our separation from and superiority over the painting.

In stripping away our eyelids, however, Kleist strips away our means of framing and processing the image as a totality. ${ }^{28}$ As many reviewers have noted, both Friedrich's painting and Kleist's ideas can be related to the Kantian sublime, since the painting and the experience of viewing without eyelids expose the viewer to an experience of the unlimited. ${ }^{29}$ With no bounded or measurable forms, no scale, and no perspective for evaluating this alien environment, the eye cannot gain ascendency over what it sees. Moreover, the lidless eye cannot determine what, how, or even whether it sees. It is absorbed into something beyond calculation that it cannot control. However, Kleist's discovery does not lead to a Kantian-inspired dialectic of the sublime that 
ultimately leads back to a concept. For Kant, of course, the struggles of the mind to grasp the infinite sensation of something too large, too dark, or too extreme, as well as its failure to tie what it perceives to a conceptual understanding, leads to an infinite oscillation, a back-and-forth between sensual impression and conceptual thinking. Kant then resolves this struggle by claiming that the oscillation becomes itself the adequate expression of the concept of the sublime. Yet for Kleist, the loss of control is just that: a loss of control. Ceasing the struggle to define something without definition, the eye surrenders to the image and cedes authority to it. To continue Kleist's metaphor, the spectator relinquishes a piece of himself to the painting. Yet this wounding cuts both ways; for while the destruction of framing devices deprives us of resistance and distance to this optical onslaught, the directionality of the encounter is not necessarily onesided. The nomadic existence of the eye within Kleist's all-consuming image also culminates in new liberties for the viewing subject, more so than Friedrich's painting. With the evocative arena opened up in Der Mönch am Meer, the artist does not overtly proscribe reactions, but he does gently guide them through the constraints of a given framework. Where Friedrich constructs for us a generous space to fill, Kleist imposes no limits and offers only space, so that the violent loss of our eyelids is our radical gain of freedom for aesthetic response.

Such violence frequently shocks Kleist's literary worlds; from the rape of the Marquise von $\mathrm{O}$ to the earthquake in Chili, these brutal events wound the bodies of his characters and rip apart the seams of the symbolic order for better and for worse. Achieving rupture through visceral means, an art that induces the sense of having had one's eyelids sliced off leaves a lasting impression, changing the viewer in some small but noticeable way. It causes us, as spectators, to see (and to see art) in a new light, with fresh eyes unobstructed by the blinders of conventional dogma. Kleist is right to invoke the Apocalypse. From the Greek word for "lifting 
of the veil" or "revelation," this designation for Kleist's imagining of abstract art exemplifies both concepts in a way that was extraordinary at the beginning of the nineteenth-century. His apocalyptic void not only brings about the destruction of the physical world, at least as it appears in art; it also opens the eyes of the viewer by unveiling a revelatory vision of what art can be and do.

\section{The Waste Land}

In the closing lines of his commentary, though, Kleist acknowledges that his revelation of what we would now call abstract art is only a prophecy yet to be fulfilled. While Der Mönch am Meer inflames the author's own artistic passions, Friedrich never actually crosses the line from transcription into creation. Be that as it may, Kleist still appreciates the artist's innovative approach and lauds his forays into abstraction at the close of his article:

Gleichwohl hat der Maler zweifelsohne eine ganz neue Bahn im Felde seiner Kunst gebrochen; und ich bin überzeugt, da $\beta$ sich, mit seinem Geiste, eine Quadratmeile märkischen Sandes darstellen ließe, mit einem Berberitzenstrauch, worauf sich eine Krähe einsam plustert, und da $\beta$ dies Bild eine wahrhaft Ossiansche oder Kosegartensche Wirkung tun müßte. Ja, wenn man diese Landschaft mit ihrer eigenen Kreide und mit ihrem eigenen Wasser malte; so, glaube ich, man könnte die Füchse und Wölfe damit zum Heulen bringen: das Stärkste, was man, ohne allen Zweifel, 
zum Lobe für diese Art Landschaftsmalerei beibringen kann. (327-

28)

Even if the territory between Friedrich's abstracted seascape and Kleist's abstract void is wide and uncharted, the writer nevertheless recognizes in Der Mönch am Meer the opening of a "ganz neue[n] Bahn.” In a testament to Friedrich's technical expertise and revolutionary aesthetics, Kleist presents the antithesis of Der Mönch am Meer: instead of a solitary monk standing on a dune before an infinite expanse of sea, a scavenging crow roosts in thorny shrubbery on a spatially and geographically determinate square mile of Prussian sand. Invoking the verses of Ossian and Kosegarten, Kleist seems to insist that even the most odious of landscapes becomes poetry under the artist's brush. ${ }^{31}$ Friedrich could work from a Spartan framework assembled from uninviting, unpleasant, and unattractive objects, and still create a moving and evocative experience for the spectator.

At the same time, this very paean to Friedrich's talents and initiative also points to the fundamental limitations of his approach. For Kleist, the critical weakness lies not with the choice of objects structuring the framework, but with the fact that the artist presents any objects or framework at all. The new direction in which his art advances leads unequivocally away from an art that mimetically reproduces the objective world. To be sure, every attribute of this final image is a calculatedly extreme exaggeration of the conventions and values championed by the tradition of Western illusionism. Reason and realism at its most radical, the crow tableau is illusionism par excellence. An image made with its own chalk and its own water, it transforms the two-dimensional forms on canvas into the three-dimensional objects they depict. ${ }^{32}$ In fact, the illusion of perceptual reality is so complete and so perfect that foxes and wolves mistake it for an 
actual landscape and are set howling by it. ${ }^{33}$ Rather than proceeding along the "ganz neue Bahn" of abstraction, this art remains entrenched in an earthen framework.

But what can a tromp-l'œil of dirt and water $d o$, aesthetically speaking, for its human audience? Compared with the monk's dramatic confrontation with the enormity of Nature, this dreary prairie is unexciting, uninspired, and laden with the physicality of its objects. It will not suggest profound metaphysical mysteries, it will not arouse overwhelming sentiments, and it most certainly will not make its spectator feel lidless. From the prickly barberry bush to an illtempered crow, nothing here is particularly welcoming; rather, it is more likely to repel any desire for absorption. As far as the author is concerned, the strongest praise one could lavish on this kind of landscape is that it fools animals. Thus, this utterly anti-abstract art is a dead-end. In order to generate a more evocative aesthetic experience; to broaden the expressive possibilities of art; to show what lines cannot form and communicate what words cannot formulate, we must head in the opposite direction. We must move away from the natural world and away from conventional painting, and toward the brave new world of abstraction.

And this is where Kleist comes to an abrupt halt. After envisioning a revolutionary future for painting; after imagining a new register of abstraction; and even after showing us how to reach this destination, the author simply stops. With his infamous dash, he then adds one last sentence to his text:

—Doch meine eigene Empfindungen, über dieses wunderbare Gemälde, sind zu verworren; daher habe ich mir, ehe ich sie ganz auszusprechen wage, vorgenommen, mich durch die Äußerungen derer, die paarweise, von Morgen bis Abend, daran vorübergehen, zu belehren. (328) 
Professing his own "Empfindingen" regarding Der Mönch am Meer to be "zu verworren," Kleist chooses not to articulate them and listens instead to the presumably insipid comments of his fellow museumgoers, who, in all likelihood, are members of the bourgeoisie. Is he conceding that the world of abstraction is perchance a bit too new and too brave for now? Does the dash represent the author's inability to express his confused sentiments? Or is it symbolic of the communicative limitations of Western illusionism?

And what are we to make of the "after-dash" barb at a caste whose tastes dominate greater society? Kleist's satirical take on bourgeois art consumption typifies the middle-class patron as unable or unwilling to really open their eyes to the significance of Friedrich's painting. That the public processes the painting "paarweise" already diminishes any true appreciation of the artwork, as Friedrich's invitation to identify with the solitary monk presupposes a personal and individual encounter. Blind to the artist's address, the pairs pass by without pause, but not without superficial and disassociated evaluation. Even if they lack insight into the evocative qualities of the painting, this does not preclude them from pretending otherwise. Kleist's oblique remark about learning from incidental commentary suggests that its speakers believe their opinions to be of intellectual and didactic value. Whereas they wax philosophical with quickly formed judgments all too easily put into words, Kleist is speechless, merely listening and contemplating the complexity of his own response. To that end, the dash could be the distinguishing marker dividing the author's perspicacity from the philistine frivolities of the unperceptive public. Whatever Kleist's original intention may have been, the hyphenated break is a proper poetic gesture of the rupture between where painting stands in 1810 and what Kleist envisages for the future. It is the difference between transcription and creation, between abstracted art and abstract art. 


\section{The Road Eventually Taken}

I have presented a "ganz neue Bahn" toward an abstract art defined by the loss of internal and external framing devices, which proceeds from the absence of internal division between foreground and background, as well as the lack of external control mechanisms. The abstracted seascape painted by Friedrich in Der Mönch am Meer marks my point of entry onto this path, for his monochrome palette, dissolution of line, and liberal manipulation of perspective result in an exceptionally empty and atypical picture. Although Friedrich embarks upon this path in the first decade of the nineteenth century and defies the public expectations that guided the normative landscape painting of his day, he does not cross the threshold from abstracted art into full abstraction. That feat is achieved by his contemporary Kleist, who, in his commentary "Empfindungen vor Friedrichs Seelandschaft," perceives in Der Mönch am Meer the inception of this very path, and even more remarkably, visualizes its terminus with a piece of abstract art. His article presents this picture of pure nothingness as a bearer of aesthetic potency whose imminent emptiness immerses the spectator in a transcendental realm where forms are indistinct and emotions immediate. Furthermore, Kleist recognized that the aesthetic effect of this image, in its fundamental difference from traditional landscapes, heralded a redefinition of what art is and does. He leaves the reader with a revelation of how art beyond Western illusionism can look and feel, in order to create an unexpected yet moving aesthetic experience.

Whether the author would have arrived at this new world had he not first encountered Der Mönch am Meer is debatable, but I believe that this instance of abstract art was borne from a symbiotic relationship of sorts. Kleist most likely needed to see the unfilled space in Friedrich's painting with his own eyes before his mind's eye could visualize an unfilled space as a painting. 
Likewise, Friedrich, with his radically empty composition, may have abstracted from all kinds of norms involving the illusionist tradition and landscape conventions, but his work needed Kleist's imagination to envision the kind of revelatory art that could arise from such revolutionary techniques. Thus, the artist created the conditions for the Apocalypse, but the author created the Apocalypse itself. Of course, Kleist unfortunately never saw such an image on canvas; his work of art, though conceived as early as 1810 , would remain trapped in written form and was not translated into painting for at least another century.

When was the world ready for the Apocalypse, so to speak? The twentieth century has witnessed numerous and diverse forms of abstract art, but the most provocative manifestations of such abstraction, both visually and philosophically, are the monumental color field paintings of America after the Second World War, particularly the work of Mark Rothko and Barnett Newman. ${ }^{35}$ Their fields of overwhelming size and overpowering color achieve a dynamic where the spectator enters an unframed realm of metaphysical space and sensation. Whether absorbed into the red world of Newman's Vir Heroicus Sublimis or consumed by Rothko's amorphous spaces, the spectator can neither distance nor restrict the pulsating presence of the paintings. Yet that is precisely the point, as Rothko writes:

To paint a small picture is to place yourself outside experience, to look upon an experience as a stereopticon view or with a reducing glass. However you paint a larger picture, you are in it. It isn't something you command. (qtd. in Harrison 196)

What Rothko describes is an aesthetic encounter that renders the spectator lidless; no framing devices separate painting from person or offer orientation through these luminous worlds. Without external control mechanisms or internal points of reference, we are placed effectively 
inside these abstract artworks as "der einsame Mittelpunkt im einsamen Kreis.” Rothko referred to this experience as "religious;" Newman called it a "revelation." Both terms illustrate the highly spiritual and emotional nature of an encounter with something greater than reason and greater than oneself, and both terms are redolent of Friedrich and Kleist (Kingsley 35, 80). While we recognize vestiges of Friedrich's abstracted seascape in their seas of abstract color, these twentieth-century creations more closely answer Kleist's prophetic call for an apocalyptically abstract art able to pull the earth out from under our feet and strip the eyelids off any viewer.

${ }^{1}$ Traditionally, scholars have traced the beginning of abstraction to the early decades of the twentieth century with Kandinsky's art and writings. For discussions of nineteenth-century predecessors to abstract art, see David Britt, Modern Art: Impressionism to Post-Modernism (London: Thames \& Hudson Ltd., 1989); Stephen F. Eisenman, Nineteenth Century Art: A Critical History (London: Thames \& Hudson Ltd., 2007); John Golding, Paths to the Absolute: Mondrian, Malevich, Kandinsky, Pollock, Newmann, Rothko and Still (London: Thames \& Hudson Ltd., 2000); Edward Weisberger, The Spiritual in Art: Abstract Painting, 1890-1985 (New York: Abbeville Press, 1986).

${ }^{2}$ Kleist first published his response to Der Mönch am Meer in the edition from October 13, 1810 of his short-lived daily, the Berliner Abendblätter. This text is not the original version, which was penned by Clemens Brentano and Achim von Arnim, but subsequently amended by Kleist. The discrepancies between the two versions have been dissected to varying degrees at the hands of several scholars (see Miller, Begemann, Börsch-Supan, Brown, Burwick, Kurz, and Müller). I will neither supplement these treatments, nor do I consider them relevant for this discussion. The words and images from the substantial amount of text inserted into the original version was 
written by Kleist himself. What remained of Brentano and Arnim's critical and biting text was retained only because it expressed Kleist's ideas and intentions, or at least was edited to do so. See Miller (esp. 210), Begemann, Burwick, and Kurz.

${ }^{3}$ For material addressing Friedrich as a precursor to abstract or modern art, see especially Bridgwater; Börsch-Supan, Caspar David Friedrich; Brown; Koerner; Morgan; Rosenblum; Sumowski; and Miller.

${ }^{4}$ This is not intended as an in-depth treatment of the innovative qualities of Friedrich's Der Mönch am Meer. I only highlight the features most pertinent for the current discussion. For further reference, see Begemann, Hofmann, (esp. 55-82), Koerner (esp. 142-46), and Zeeb.

${ }^{5}$ Several scholars (Sumowski, Miller, Koerner, Rosenblum) have mentioned abstraction in relation to Friedrich, but again, they point to his innovative work as a prefiguration of twentiethcentury abstract art.

${ }^{6}$ See Börsch-Supan, “Caspar David Friedrich’s Landscapes with Self-Portraits,” and Hofmann. Börsch-Supan credits himself as the first to identify the monk as a self-portrait. He writes: "the thick fair hair, the sprouting beard, the round-shaped skull and the gaunt stature are features of Friedrich's appearance as it is known from authenticated portraits and written descriptions" (624). Reinhard Zimmermann has brought the identity of the monk into question, as no evidence has been found where Friedrich actually names the figure as such. Brentano was the first to use the term "Kapuziner" (226-27). Busch would seem to confirm that the monk was initally not so; 
using technology, research, and close observation, he notices that the telltale robe was added later (59-64).

${ }^{7}$ For an overview of prevailing attitudes toward art at the time, see Börsch-Supan, "Berlin 1810.”

${ }^{8}$ For a more detailed explication of traditional landscape painting and its visual consumption, see Begemann 13-17, Hofmann 21-22, and Goldfarb.

${ }^{9}$ See Koerner 100-12 for more on Meeresstrand im Nebel.

${ }^{10}$ Practically every scholar who treats the painting mentions Friedrich's initial inclusion and subsequent deletions of these objects. See Börsch-Supan, "Bemerkungen.” More recently, Werner Busch has shown to what extent this painting really is a "Palimpsest," reasserting an observation from 1983: a sketch of Rügen's southern coast dated August 17, 1801 features in the foreground "eine wörtliche Übertragung, bis ins kleinste Detail" of the "gesamte öde Strandstück, auf dem der Mönch steht," while in the background tress and fields fill out the lower left half (49). For his painting, Friedrich eliminated everything from this drawing save for the strip of sand. See Busch, esp. 49-55. For Busch's meticulously researched and fascinating treatment of this picture, its composition, and how "[d]er ästhetische Eigensinn des Bildes [...] vorherrschend [bleibt]," see 46-81.

${ }^{11}$ After visiting Friedrich's atelier, Jena publisher Karl Friedrich Frommann recorded in his diary how Der Mönch am Meer showed “die Ostsee mit schön blinkenden Wellen beim letzten Viertel des Mondes und dem schwach blitzenden Morgenstern," while X-rays reveal two ships on each side of the monk. Moon, star, and sailing vessels were eventually painted over by Friedrich 
before the 1810 exhibition. Frommann's diary entry is dated September 24, 1810. See BörschSupan and Jähnig.

${ }^{12}$ For further reading on absence in Romantic landscape painting, see Kuzniar.

${ }^{13}$ In addition to Friedrich's departure from Western illusionism, Ramdohr condemned what he saw as discrepancies between the painting and its frame, as well as its perceived failures on the allegorical level. For closer readings of the Ramdohr dispute see Busch 34-45, Hofmann 41-52, Koerner 117-26 and 147-59, and Drügh 189-93.

${ }^{14}$ In a study of Friedrich's fog, Johannes Grave reveals how the cloud-effects also obscured the viewer's attempt to perceive clear meaning or signification in the artist's work. As a result, "was dem Rezipienten bleibt, ist die nicht näher determinierte Anregung seiner 'Phantasie,' seiner 'Einbildungskraft'”' (398).

${ }^{15}$ In a letter dated June 22, 1809, Marie Helene von Kügelgen characterized the sky in an early version as "clear and indifferently calm," what hardly describes the overcast and ominous one in the current painting (qtd. in Lambert 245).

${ }^{16}$ For greater discussion of the painting's structural disruptions, see Börsch-Supan, “Bemerkungen," especially 64-66; Grave Glaubensbild und Bildkritik; and Kuzniar, "The Temporality of Landscape.”

${ }^{17}$ Morton generalizes Friedrich's juxtapositions of nearness and distance as “metaphors for moments of confrontation with the divine" (“German Romanticism” 12), while Kuziniar more 
specifically describes how the artist used such spatial arrangements as a means of structuring discontinuous linear time in "The Temporality of Landscape."

${ }^{18}$ Miller proposes that it might have been the first painting to feature an ocean without vessels (207).

${ }^{19}$ All Friedrich citations are quoted from Börsch-Supan, "Berlin 1810” 74. Reinhard Zimmermann rightly emphasizes the importance of Friedrich's written thoughts (“Gedanken”) for the development of his aesthetics. Zimmermann employs the term "Bildgedanken" to refer to these writings, differentiating them from mere "Beschreibungen," a distinction the artist himself makes as evidenced by this particular citation. Friedrich on several occasions stressed "die Relevanz von 'Gedanken’ als konstitutiver Momente eines Bildes” (188). Zimmermann recounts how Friedrich intensively formulated and reformulated these "Gedanken" as he experimented with various compositional structures and motifs.

${ }^{20}$ Gustav Carus summarizes the dominant interpretation of the Rückenfigur as the "site of identification or mediation between painting and viewer, nature and consciousness, finite and infinite" (Koerner 245-46). For additional treatments of the device, see Koerner ch.10, 210-28; Simson 20-21; and Bridgwater 118-27. Kroeber offers an alternative interpretation in which he perceives Friedrich's Rückenfiguren as impeding the viewer's participation in the picture. Given the extent to which Friedrich conditions readers' engagement in his writings, I believe that the artist envisioned interaction between spectator and painting and thus conceived the Rückenfigur as a device to invite participation. See Kroeber. That being said, Busch has brought to my attention the likelihood that this Rückenfigur originally faced toward the audience, turned off to 
the side in contemplation. Moreover, he locates a possible inspiration for the original pose in an illustration for Goethe's Faust done by one of Friedrich's Dresden contemporaries, which leads him to offer the possibility that the monk "faustische Anwandlungen der Selbstüberhebung haben [mag]," though the picture shows us "wie eitel und töricht ein solches Unterfangen ist" $(62-64)$.

${ }^{21}$ While interpretations often place the monk on the Golden Section (see, for example, Hofmann 91), Busch's careful study of the geometric composition and aesthetic structure underlying Friedrich's paintings reveals the surprising absence of one of the artist's favored devices: 'Keine Linie des Goldenen Schnitts greift bei diesem Bild, auch kein anderes ästhetisches Ordnungsgebilde ist genutzt" (76). Busch thus underscores all the more the abstraction of this painting without actually characterizing it as abstract art.

${ }^{22}$ In light of Friedrich's spiritualism, many scholars read an explicitly religious character into the painting. While I certainly perceive the presence of a divine dimension, I do not believe Friedrich's work should be reduced to only religious readings.

${ }^{23}$ Begemann, Börsch-Supan, and Janz relate the tension between "Anspruch" and "Abbruch" to the Romantic conception of "Sehnsucht." Begemann sees this conception as inherently dynamic and Dionysian (8), while Janz views "Sehnsucht" as a Romantic project arising from unfulfilled and continual longing for boundlessness with longing being a goal in itself (140).

${ }^{24}$ The eyelid metaphor was likely not Kleist's invention, but, as Peter Bexte argues, appropriated from Cicero's account of Regulus, a Roman consul captured by the Carthaginians, punished 
through the removal of his eyelids, and thrown into the sun to be blinded. Countering predominant scholarly interpretations involving framelessness, the Sublime, or panoramas, Bexte stresses the "blinding" effect of the image on the eye ("Antike Blendung," "Die weggeschnittenen Augenlider des Regulus”). While I agree that Friedrich’s painting has a powerful effect on the eye, I am not convinced by a reading where the eye is "blinded" by the image, especially at the expense of other interpretations. Moreover, I do not necessarily believe that Kleist understood his own use of the metaphor solely in terms of blinding, if at all. In her articles, Kuzniar does use the term "blinding," but not as a consequence of overpowering light. Rather, the inability of the eye to traverse linear and temporal distances in the painting, coupled with a semiotic shift away from natural referents, results in a "blinded" viewer ("The Vanishing Canvas" 369-70; "The Temporality of Landscape" 78, 84).

25 The novelty of this violent moment has been much discussed. Begemann writes: "Von blutiger Verletzung ist die Rede, von einem unerhörten Eingriff in die Autonomie des Leibes und die Person” (16). For Janz, this moment signals “einen ästhetischen Skandal” (144-45), while Jörg Zimmermann notes how this "Metaphorik der Verleztung wurde als Antizipation von SchockGesten der ästhetischen Moderne gedeutet” (125). Seeba characterizes the metaphor as an "epistemological image" indicative of Kleistian desperation over the "impossibility of welding signifier and signified into one," proposing mutilation as a means of "overcoming the distance between subject and object" and accessing truth $(115,116)$. In his project, Seeba examines how Kleist's eye imagery reflects “epistemological disorders" involving the perception of truth, which stem from the author's "Kant-Krise." 
${ }^{26}$ Begemann also delineates the importance of eyelids for human perception and how the seeing subject's reaction to the onslaught of optical input is affected by the loss of these framing mechanisms (13-17). He connects these implications to the rise of the panoramic picture (“Gemälde ohne Grenzen”) and the rise of a more empowered viewer (17-22). Brown's reading likewise implicates the popularity of panoramic media (194-206), as does Müller's (210-17). Börsch-Supan connects Kleist's metaphor to the horizontality of the expanse, but also discerns the implicit degree of pain involved, resulting from the eye being forced to occupy a passive mode of seeing ("Bemerkungen” 72). While Grave does not discuss panoramic vision, he also interprets the lidless eye as signifying a mode of viewing that exceeds the spectator's control due to the absence of internal framing devices. As a consequence, the painting exerts power over those who view it.

${ }^{27}$ For an analysis of Penthesilea that addresses the violation of limits between subject and object and the consequences for Kantian aesthetics, see Chaoli.

${ }^{28}$ Begemann and Kuzniar also interpret Kleist's eyelid imagery in terms of framing and the spectator's ability to gain ascendency over that which is seen.

${ }^{29}$ For more comprehensive treatments of Kleist's text, Friedrich's painting, and their relation to Kant's, Schiller's, and Goethe's discussions of the sublime, see Janz, Zeeb, and Greiner as well as Jörg Zimmermann.

${ }^{31} \mathrm{I}$ am grateful to Bernd Fischer for alerting me to the possibility of nationalistic undertones in this passage. The explicit mention of a "Quadratmeile märkischen Sandes," coupled with allusions to Ossian, the "Celtic Homer" and source of Scottish pride, and Kosegarten, the pastor- 
poet whose verses immortalize the shores of Rügen, could suggest a specifically German quality inherent in Friedrich's art. Although Busch strongly argues against oversimplified interpretations of the artist's oeuvre that stress nationalism (or religiosity), he does indicate that the monk could signify anti-French sentiments of the time, as mendicant orders such as the Capuchins were known opponents of Napoleon (65).

32 Janz even calls it "hyperrealism ad absurdum" and interprets it as a shrewd allusion to normative landscape painting (146).

${ }^{33}$ This passage could allude to the Greek artist Zeuxis, who painted grapes so mimetically perfect that birds attempted to eat them (Greiner, "Die $>$ unmögliche $<$ Wende" 34). Brinkmann argues against interpretations that stress mimesis, reading the beastly reactions as a testament to the emotional power of the picture and finding support in the references to Kosegarten and Ossian. Jörg Zimmermann (127) and Greiner ("Die > unmögliche $<$ Wende") also read this passage as indicative of a more pathological response, comparing the howls of the foxes and wolves to the howling of leopards and wolves in Kleist's 1810 novella, "Die heilige Cäcilie." ${ }^{35}$ In his work on the Abstract Sublime, Robert Rosenblum has already noted the visual correlations between Friedrich's "visionary nature-painting” and the monumental landscapes of the Abstract Expressionists (161). The link between German Romanticism and Abstract Expressionism is persuasive, but I perceive a more direct route between Kleist's image and those of color field painters. For more on the Abstract Expressionists, see Kingsley and Harrison. 


\section{Works Cited}

Begemann, Christian. “Brentano und Kleist vor Friedrichs Mönch am Meer. Aspekte eines Umbruchs in der Geschichte der Wahrnehmung." Deutsche Vierteljahrsschrift für Literaturwissenschaft und Geistesgeschichte 64.1 (1990): 89-145.

Bexte, Peter. “Augenlider weggeschnitten. Antike Blendung: Cicero als Quelle für Kleists Diktum zu Friedrichs Mönch am Meer.” Süddeusche Zeitung 6 Feb. 2009: 14. . "Die weggeschnittenen Augenlider des Regulus. Die verdeckten Antikenrezeption in einem Wort Heinrich von Kleists.”Kleist-Jahrbuch. Berlin: Erich Schmidt Verlag, 2008/2009. 254-66.

Blankenagel, John C. “The Dominant Characteristics of German Romanticism.” PMLA 55.1 (1940): 1-10.

Börsch-Supan, Helmut. "Bemerkungen zu Caspar David Friedrichs 'Mönch am Meer.'” Zeitschrift des Deutschen Vereins für Kunstwissenschaft, 19 (1965): 63-76. . "Berlin 1810. Bildende Kunst: Aufbruch unter dem Druck der Zeit.” Kleist-Jahrbuch. (1987): 52-76.

. "Caspar David Friedrich's Landscapes with Self-Portraits." The Burlington Magazine 114.834 (1972): 620-30.

. Caspar David Friedrich. Munich: Prestel, 1990.

Bridgwater, Patrick. "Friedrichian Images in Expressionist Art.” Oxford German Studies 31 (2002): 103-28.

Brinkmann, Bodo. "Zu Heinrich von Kleists 'Empfindungen vor Friedrichs Seelandschaft."” Zeitschrift für Kunstgeschichte 44.2 (1981): 181-87. 
Britt, David. Modern Art: Impressionism to Post-Modernism. London: Thames \& Hudson Ltd., 1989.

Brown, H.M. ““Zwischen Erde und Himmel': Kleist and the Visual Arts, with Special Reference to Caspar David Friedrich.” German Life and Letters 31.2 (1978): 157-66.

Burwick, Roswitha. "Verschiedene Empfindungen vor Friedrichs Seelandschaft: Arnim, Brentano, Kleist.” Special Issue of Zeitschrift für deutsche Philologie 107 (1988): 33-44.

Busch, Werner. Caspar David Friedrich. Ästhetik und Religion. Munich: Verlag C.H. Beck, 2003.

Chaoli, Michel. "Devouring Metaphor: Disgust and Taste in Kleist's Penthesilea." The German Quarterly 69.2 (Spring 1996): 125-43.

Drügh, Heinz J. "Präsenzen und Umwege_Kleists medienanalytische Ekphrasis." Darstellbarkeit: zu einem ästhetisch-philosophischen Problem um 1800. Ed. Claudia Albes and Christiane Frey. Würzburg: Königshausen \& Neumann, 2003. 181-208. Eisenman, Stephen F. Nineteenth Century Art: A Critical History. London: Thames \& Hudson Ltd., 2007.

Goldfarb, Hilliard T. "Naïve and Sentimental' Landscape: Schiller, Hackert, Koch, and the Romantic Experience.” The Bulletin of the Cleveland Museum of Art 69.9 (1982): 28296.

Golding, John. Paths to the Absolute: Mondrian, Malevich, Kandinsky, Pollock, Newmann, Rothko and Still. London: Thames \& Hudson Ltd., 2000.

Grave, Johannes. "Amor als romantischer Landschaftsmaler? Nebel und Schleier bei Goethe und Caspar David Friedrich.” Zeitschrift für Kunstgeschichte 69.3 (2006): 393-401. . Caspar David Friedrich. New York: Prestel, 2012. 
. Caspar David Friedrich. Glaubensbild und Bildkritik. Zürich: Diaphanes, 2011.

Greiner, Bernhard. "Das Erhabene in der Kunst als Verrückung und als Aporie: Empfindungen vor Friedrichs Seelandschaft, das Guiskard-Projekt und der Zusammenbruch von 1803/1804.” Eine Art Wahnsinn: Dichtung im Horizont Kants: Studien zu Goethe und Kleist. Berlin: Erich Schmidt, 1994. 106-29.

. "Die > unmögliche $<$ Wende vom Erhabenen der Natur zum Erhabenen der Kunst: Empfindungen vor Friedrichs Seelandschaft.” Kleists Dramen und Erzählungen: Experimente zum 'Fall' der Kunst. Tübingen: A. Francke, 2000. 16-36.

Held, Heinz-Georg. "Paradoxie des utopischen Augenblicks: Drei Kommentare zu Caspar David Friedrichs Sehlandschaft." Weimarer Beiträge: Zeitschrift fur Literaturwissenschaft, Ästhetik und Kulturwissenschaften 39.1 (1993): 107-21.

Hofmann, Werner. Caspar David Friedrich. London: Thames \& Hudson, 2000.

Janz, Rolf-Peter. "Mit den Augen Kleists: Caspar David Friedrichs 'Mönch am Meer." KleistJahrbuch (2003): 137-49.

Koerner, Joseph Leo. Caspar David Friedrich and the Subject of Landscape. London: Reaktion Books Ltd, 1990.

Kleist, Heinrich von. "Empfindungen vor Friedrichs Seelandschaft.” Sämtliche Werke und Briefe. Vol. 2. Munich: Carl Hanser Verlag, 1965. 327-28.

Kroeber, Karl. "The Clarity of the Mysterious and the Obscurity of the Familiar: Friedrich and Turner." The Romantic Imagination: Literature and Art in England in Germany. Ed. Frederick Burwick and Jürgen Klein. Atlanta: Rodopi, 1996. 338-412. 
Kurz, Gerhard. "Vor einem Bild. Zu Clemens Brentanos 'Verschiedene Empfindungen vor einer Seelandschaft von Friedrich, worauf ein Kapuziner."' Jahrbuch des Freien Deutschen Hochstifts (1988): 128-40.

Kuzniar, Alice A. "The Temporality of Landscape.” Studies in Romanticism 28.1 (1989): 69-93. . “The Vanishing Canvas.” German Studies Review 11.3 (1988): 359-76.

Lambert, Sterling. "Franz Schubert and the Sea of Eternity." The Journal of Musicology 21.2 (2004): 241-66.

Miller, Philip B. "Anxiety and Abstraction: Kleist and Brentano on Caspar David Friedrich.” Art Journal 33.3 (1974): 205-10.

Morgan, David. "The Enchantment of Art: Abstraction and Empathy from German Romanticism to Expressionism.” Journal of the History of Ideas 57.2 (1996): 317-41.

Morton, Marsha. "German Romanticism: The Search for 'A Quiet Place."” Art Institute of Chicago Museum Studies 28.1 (2002): 8-23, 106-07. . "Johann Erdmann Hummel and the Flemish Primitives: The Forging of a Biedermeier Style.” Zeitschrift für Kunstgeschichte 52.1 (1989): 46-67.

Müller, Gernot. Man müßte auf dem Gemälde selbst stehen: Kleist und die bildende Kunst. Tübingen: A. Francke, 1995.

Rosenblum, Robert. "The Abstract Sublime.” The Abstraction of Landscape: From Northern Renaissance to Abstract Expressionism. Madrid: Fundación Juan March, 2007. 161-66. Saisselin, R.G. "Art as an Imitation of Nature." The Bulletin of the Cleveland Museum of Art 52.2 (1965): 34-44. 
Seeba, Hinrich C. "The Eye of the Beholder: Kleist's Visual Poetics of Knowledge.” $A$

Companion to the Works of Heinrich von Kleist. Ed. Bernd Fischer. Columbia: Camden House, 2003. 103-22.

Shahar, Galili. "Fragments and Wounded Bodies: Kafka after Kleist. The German Quarterly 80.4 (2007): 449-67.

Siegel, Linda. "Synaesthesia and the Paintings of Caspar David Friedrich.” Art Journal 33.3 (1974): 196-204.

Simson, Otto von. Der Blick nach Innen: Vier Beiträge zur deutschen Malerei des 19. Jahrhunderts. Berlin: Edition Hentrich, 1986.

Traeger, Jörg. “...As if one's Eyelids had been Cut Away: Imagination in Turner, Friedrich, and David." The Romantic Imagination: Literature and Art in England in Germany. Ed. Frederick Burwick and Jürgen Klein. Atlanta: Rodopi, 1996. 413-35.

Weber, Bruno. Gottfried Keller: Landschaftsmaler. Zürich: Verlag Neue Zürcher Zeitung, 1990. Weber, Richard A. Color and Light in the Writings of Eduard von Keyserling. New York: P. Lang, 1990.

Weisberger, Edward. The Spiritual in Art: Abstract Painting, 1890-1985. New York: Abbeville Press, 1986.

Zeeb, Ekkehard. 'Kleist, Kant und / mit Paul de Man—vor dem ‘Rahmen’ der Kunst. Verschiedene Empfindungen vor Friedrichs Seelandschaft." Heinrich von Kleist: Kriegsfall—Rechtsfall—Sündenfall. Ed. Gerhard Neumann. Freiburg im Breisgau: Rombach, 1994. 299-336.

Zimmermann, Jörg. "Bilder des Erhabenen-Zur Aktualität des Diskurses über Caspar David Friedrichs 'Mönch am Meer.” Ästhetik im Widerstreit: Interventionen zum Werk von 
Jean-François Lyotard. Ed. Christine Pries and Wolfgang Welsch. Weinheim: VCH, 1991. 107-27.

Zimmermann, Reinhard. "Das Geheimnis des Grabes und der Zukunft. Caspar David Friedrichs ‘Gedanken' in den Bilderpaaren.” Jahrbuch der Berliner Museen 42 (2000): 187-257. 